\title{
Pemeriksaan Kecacingan Secara Kualitatif pada Sapi Perah Friesian Holstein di KPGS Cikajang Garut
}

\author{
Qualitative Examination of Helminthiasis of Dairy Cows Friesian Holstein \\ in KPGS Cikajang Garut
}

\author{
Refi Yunizeta*, Tetty Barunawati Siagian \\ Program Studi Paramedik Veteriner, Sekolah Vokasi Institut Pertanian Bogor \\ ${ }^{*}$ Korespondensi penulis: e-mail : refytaa@gmail.com
}

Diterima : Februari 2021

Disetujui terbit : April 2021

\begin{abstract}
Helminthiasis in dairy cows still get less attention from farmers than other diseases. Helminthiasis causes weight loss and milk decrease. This research was done by using qualitative examination with direct slide and flotation technique. The purpose of this research is to describe qualitative examination of helminthiasis on dairy cows Friesian Holstein from farmers at KPGS Cikajang Garut. Faecal's samples were taken from 82 dairy cows. The samples feces were taken randomly from dairy cows's rectum. The samples were put in a ziplock plastic to do qualitative examination using direct slide and flotation technique. The results of the examination showed negative results from 82 samples. The negative results caused by dairy cows have been given routine medication anthelmintic and good sanitation. Anthelmintic that is usually given to dairy cows are Albenol$2500 \Theta$ (Albendazole $2500 \mathrm{mg}$ ) given orally mixed with cow feed, Intermectin $\Theta$ (Ivermectin $10 \mathrm{mg}$ ),

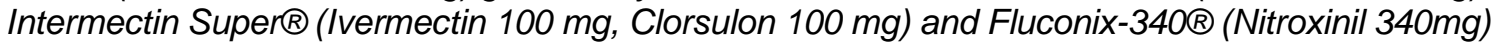
was applied subcutaneously.
\end{abstract}

Keywords : feces, helminthiasis, direct slide, flotation technique, dairy cows

\begin{abstract}
ABSTRAK
Infeksi kecacingan (helminthiasis) pada sapi perah masih kurang mendapat perhatian dari para peternak dibandingkan penyakit lain. Helminthiasis menimbulkan kerugian berupa penurunan berat badan dan produksi susu. Penelitian ini dilakukan secara kualitatif dengan metode natif dan metode pengapungan (flotasi sederhana). Tujuan dari penelitian ini adalah untuk menguraikan informasi mengenai pemeriksaan kecacingan secara kualitatif pada sapi perah Friesian Holstein dari beberapa kelompok peternak di KPGS Cikajang Garut. Sampel yang digunakan yaitu feses sapi perah yang diambil dari beberapa kelompok peternak di KPGS Cikajang Garut. Sampel feses diambil dari 82 ekor sapi perah. Sampel yang diambil adalah feses segar yang diambil langsung dari rektum sapi secara acak. Kemudian sampel dimasukkan ke dalam plastik ziplock untuk dilakukan pemeriksaan kualitatif feses. Pemeriksaan kualitatif yang dilakukan yaitu natif dan pengapungan. Hasil pemeriksaan terhadap 82 sampel feses menunjukkan hasil negatif. Hasil negatif disebabkan sapi perah tersebut telah diberi obat anti cacing secara rutin dan pemeliharaannya dilakukan secara baik. Obat anti cacing yang biasa diberikan pada sapi perah di KPGS Cikajang adalah Albenol-2500 ${ }^{\circledR}$ (Albendazole $2500 \mathrm{mg}$ ) diberikan secara per oral yang dicampur pakan sapi, Intermectin ${ }^{\circledR}$ (Ivermectin $10 \mathrm{mg}$ ), Intermectin Super ${ }^{\circledR}$ (Ivermectin 100 mg, Clorsulon $100 \mathrm{mg}$ ) dan Fluconix-340 ${ }^{\circledR}$ (Nitroksinil $340 \mathrm{mg}$ ) yang diaplikasikan secara subkutan. Kata kunci : feses, kecacingan, metode natif, metode pengapungan, sapi perah
\end{abstract}




\section{PENDAHULUAN}

Pemeliharaan sapi perah ditujukan untuk menghasilkan susu yang berkualitas untuk dikonsumsi. Sapi perah harus selalu dipastikan dalam kondisi sehat. Peternakan yang dipelihara secara modern atau yang dipelihara secara tradisional tidak lepas dari berbagai hambatan dan kendala termasuk infeksi cacing. Salah satu penyebab penurunan jumlah dan kualitas susu pada sapi perah yaitu infeksi kecacingan. Menurut Zalizar (2017) dan Andrianty (2015), infeksi kecacingan pada sapi perah dapat menyebabkan penurunan produksi susu dan hambatan pertumbuhan sapi. Infeksi ini umumnya terjadi secara kronis dan menimbulkan gejala subklinis serta jarang menimbulkan kematian. Kondisi ini menyebabkan infeksi kecacingan pada sapi perah masih kurang mendapat perhatian dari para peternak dibandingkan penyakit lain. Gejala sapi yang terinfeksi kecacingan yaitu kurus, rambut kusam, diare atau bahkan konstipasi (Astiti 2010).

Koperasi Peternak Garut Selatan (KPGS) Cikajang merupakan koperasi yang menampung susu sapi dari peternak di sekitar Cikajang. Koperasi Peternak Garut Selatan (KPGS) Cikajang telah melakukan program pencegahan kecacingan terhadap sapi perah milik peternak di sekitar Cikajang. Program pencegahan dan pengobatan infeksi kecacingan yang dilakukan oleh KPGS Cikajang Garut yaitu pemberian obat anti cacing (anthelmintic). Pemeriksaan feses belum dilakukan untuk mengevaluasi program pemberian obat cacing rutin yang dilakukan KPGS Cikajang Garut. Pemeriksaan kecacingan dapat dijadikan sebagai indikator ada atau tidak adanya infeksi kecacingan (Swierczynski 2010).

Berdasarkan latar belakang tersebut perlu diadakan penelitian mengenai pemeriksaan kecacingan secara kuaitatif pada sapi perah Friesian Holstein di kelompok peternak di KPGS Cikajang Garut. Tujuan penelitian ini adalah untuk menguraikan informasi mengenai pemeriksaan kecacingan secara kualitatif pada sapi perah Friesian Holstein di kelompok peternak di KPGS Cikajang Garut.

\section{METODE}

\section{Metode Natif dan Metode Pengapungan}

Penelitian dilakukan secara kualitatif dengan metode natif dan metode pengapungan (flotasi sederhana). Pemeriksaan feses secara kualitatif, yaitu pemeriksaan yang didasarkan pada ditemukan telur cacing pada saat pemeriksaan tanpa perlu dihitung jumlahnya (Marhani 2012). Pemeriksaan 
kualitatif meliputi pemeriksaan langsung (direct slide), metode pengapungan (flotasi sederhana), metode selotip, teknik sediaan tebal dan metode sedimentasi (Regina et al. 2018). Setiap metode memiliki kelebihan dan kekurangan masing-masing. Metode yang paling sering digunakan yaitu metode natif dan metode pengapungan. Metode natif baik digunakan pada infeksi berat karena pada infeksi ringan telur-telur cacing sulit ditemukan. Prosedur metode natif yaitu feses dicampurkan dengan 1-2 tetes aquades lalu diperiksa di bawah mikroskop. Prinsip kerja dari metode pengapungan berdasarkan berat jenis (BJ). BJ telur cacing lebih ringan daripada BJ larutan yang digunakan sehingga telur cacing terapung di permukaan dan digunakan untuk memisahkan partikel besar yang ada dalam feses. Pemeriksaan dengan metode ini menggunakan larutan gula garam jenuh yang didasarkan atas berat jenis telur cacing sehingga telur akan mengapung dan mudah diamati (Rahmadhini 2016).

Sampel yang digunakan yaitu feses sapi perah yang diambil dari beberapa kelompok peternak di KPGS Cikajang Garut mulai tanggal 14 Februari sampai 4 Maret 2019. Sampel feses diambil dari 82 ekor sapi perah. Sampel yang diambil adalah feses segar yang diambil langsung dari rektum sapi secara acak. Kemudian sampel dimasukkan ke dalam plastik ziplock untuk dilakukan pemeriksaan kualitatif feses (Siagian dan Tiuria 2018).

Alat yang digunakan dalam metode natif adalah sarung tangan (gloves), object glass, cover glass, tusuk gigi, dan spuit $3 \mathrm{ml}$ dan mikroskop. Bahan yang digunakan adalah sampel feses sapi dan larutan aquades. Metode natif dilakukan dengan mengambil sampel feses secukupnya pada plastik dengan menggunakan tusuk gigi. Sampel feses diletakkan di atas object glass bersih. Aquades ditambahkan secukupnya, kemudian sampel feses dihomogenkan dan ditutup dengan cover glass. Preparat uji natif (Gambar 1) dilihat di bawah mikroskop dengan perbesaran lensa obyektif 4 kali dan 10 kali untuk mengetahui ada atau tidak adanya telur cacing.

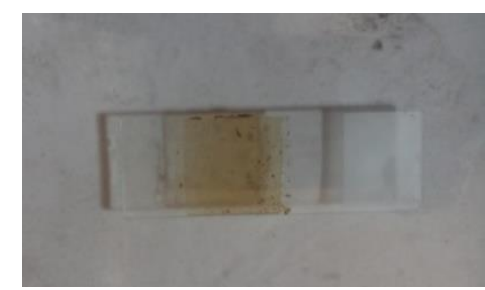

Gambar 1 Preparat metode natif

Alat yang digunakan dalam metode pengapungan adalah sarung tangan (gloves), object glass, cover glass, tusuk gigi, tabung reaksi, spuit $3 \mathrm{ml}$ dan 
mikroskop. Bahan yang digunakan adalah sampel feses sapi dan larutan gula garam jenuh. Metode pengapungan (Gambar 2) dilakukan dengan mencampur $2 \mathrm{~g}$ sampel feses dengan $58 \mathrm{ml}$ larutan gula garam jenuh. Larutan sampel dituangkan ke dalam tabung reaksi sampai membentuk meniskus cembung kemudian ditutup dengan menggunakan cover glass dan didiamkan selama 5 menit. Cover glass diangkat dan diletakkan pada object glass. Preparat uji apung diperiksa di bawah mikroskop dengan perbesaran lensa obyektif 4 kali dan 10 kali untuk mengetahui ada atau tidak adanya telur cacing (Soulsby 1986 dalam Saefullah 2012). Larutan gula garam jenuh dibuat dengan mencampur $500 \mathrm{~g}$ gula dengan $400 \mathrm{~g}$ garam kemudian ditambahkan air sampai larutan menjadi $1000 \mathrm{ml}$ dan dipanaskan hingga larutan jenuh.

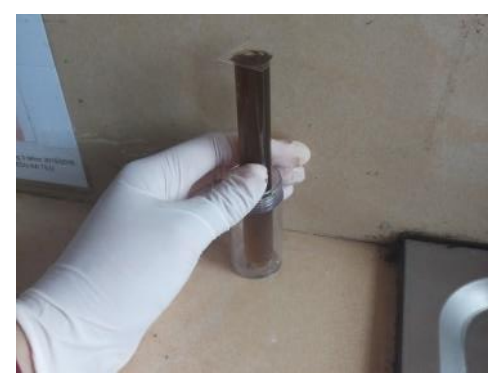

Gambar 2 Metode pengapungan

\section{HASIL DAN PEMBAHASAN}

Metode Natif dan Metode Pengapungan

Terdapat dua metode pemeriksaan sampel feses yang digunakan, yaitu metode natif dan metode pengapungan (flotasi sederhana). Setiap metode memiliki kelebihan dan kekurangan masing-masing. Metode natif (direct slide) merupakan gold standard pemeriksaan kualitatif feses karena murah, mudah dan pengerjaan cepat, namun kurang sensitif pada infeksi ringan (Regina et al. 2018). Metode natif adalah metode pemeriksaan feses secara langsung dan tanpa pewarnaan. Metode ini cepat dan efektif untuk pemeriksaan pada infeksi berat. Sampel feses pada metode natif hanya dilarutkan dengan aquades untuk melarutkan dan memisahkan partikelpartikel besar pada feses sehingga mudah diproses dan diamati. Setelah larutan aquades diteteskan pada object glass dan ditutup dengan cover glass, preparat akan mudah diamati daripada preparat tanpa pelarutan apapun (Agoes 2009 dalam Firdayana 2016).

Metode pengapungan (flotasi sederhana) digunakan untuk jenis telur cacing parasit yang dapat mengapung dengan mengunakan larutan gula garam jenuh. Jumlah sampel feses sapi yang digunakan akan mempengaruhi jumlah larutan gula garam jenuh yang 
dicampurkan. Sampel feses sebanyak $1 \mathrm{~g}$ dicampurkan dengan $29 \mathrm{ml}$ larutan gula garam jenuh (Shaikenov et al. 2004 dalam Nono 2017). Sampel feses sebanyak $2 \mathrm{~g}$ dicampurkan dengan $58 \mathrm{ml}$ larutan gula garam jenuh (Soulsby 1986 dalam Saefullah 2012). Sampel feses sebanyak $4 \mathrm{~g}$ dicampurkan dengan $56 \mathrm{ml}$ larutan gula garam jenuh (Shaikenov et al. 2004 dalam Prabowo 2016). Larutan sampel dituangkan ke dalam tabung reaksi sampai membentuk meniskus cembung lalu ditutup dengan menggunakan cover glass dan didiamkan selama 5 menit, cover glass diangkat dan diletakkan pada object glass dan diamati di bawah mikroskop (Shaikenov et al. 2004 dalam Tantri et al. 2013). Metode pengapungan (flotasi sederhana) menggunakan larutan gula garam jenuh sebagai alat untuk mengapungkan telur cacing. Metode ini terutama digunakan untuk pemeriksaan feses yang mengandung sedikit telur. Cara kerja dari metode ini berdasarkan berat jenis (BJ) telur cacing yang lebih ringan daripada BJ larutan yang digunakan, sehingga telur cacing seperti telur Cestoda dan telur Nematoda terapung di permukaan dan memisahkan partikel-partikel besar yang terdapat dalam feses. Kelebihan metode apung adalah telur cacing yang diperiksa terpisah dari kotoran sehingga menghasilkan lapang pandang yang lebih bersih, baik untuk infeksi berat dan ringan. Kekurangan metode pengapungan (flotasi sederhana) yaitu membutuhkan sampel lebih banyak dan waktu lebih lama dibandingkan metode natif (Limpomo 2014).

\section{Hasil Pemeriksaan}

Hasil pemeriksaan terhadap 82 sampel feses dengan menggunakan dua metode yaitu natif dan pengapungan (flotasi sederhana) menunjukkan hasil negatif. Artinya tidak ditemukan adanya telur cacing. Hasil negatif disebabkan sapi perah tersebut telah diberi obat anti cacing secara rutin dan pemeliharannya dilakukan secara baik oleh para peternak.

Obat anti cacing yang biasa diberikan pada sapi perah di KPGS Cikajang Garut adalah Albenol-2500® (Albendazole 2500 mg), Intermectin $\AA$ (Ivermectin $10 \mathrm{mg}$ ), Intermectin Super ${ }^{\circledR}$ (Ivermectin $100 \mathrm{mg}$, Clorsulon $100 \mathrm{mg}$ ) dan Fluconix-340® (Nitroksinil 340 mg). Pemberian obat anti cacing pada sapi perah di KPGS Cikajang Garut dimulai dari lahir sampai sapi berumur 1 tahun rutin diberikan selama 3 bulan sekali. Pemberian obat anti cacing dimulai saat sapi berumur 3 bulan. Ketika sapi berumur 1 tahun, pemberian obat anti cacing diberikan rutin setiap 6 bulan sekali atau sebelum pelaksanaan inseminasi buatan 
(IB) dilakukan. Menurut Info Medion (2013), pemberian obat anti cacing sebaiknya dilakukan sejak pedet (umur 7 hari) dan diulang secara berkala setiap 34 bulan sekali.

Albendazole adalah anthelmintic spektrum luas, efektif terhadap semua jenis cacing nematoda, trematoda dan cestoda baik stadium larva maupun dewasa. Obat ini diindikasikan untuk pengobatan cacing pada ternak sapi seperti: cacing pencernaan (Bunostomum, Cooperia, Chabertia, Haemonchus, Nematodirus, Strongyloides, Oesophagostomum, Ostertagia dan Trichostrongylus), cacing paru-paru (Dictyocaulus viviparus dan $D$. filaria), cacing pita (Moniezia spp) dan cacing hati (Fasciola hepatica dewasa). Obat ini diberikan secara per oral dengan dosis $10 \mathrm{mg} / \mathrm{kg}$ bobot badan untuk pengobatan cacing hati dan $8,3 \mathrm{mg} / \mathrm{kg}$ bobot badan untuk pengobatan selain cacing hati. Obat ini tidak boleh diberikan pada ternak bunting kurang dari 45 hari (TMC 2019).

Pemberian obat ini pada sapi perah di KPGS Cikajang dengan cara mencampurnya dengan pakan ternak Pemberian peroral obat ini, diserap oleh usus dan cepat dimetabolisme menjadi albendazole sulfoksida, sebagian besar diekskresi melalui urin dan feses. Ketika waktu paruh obat mencapai 8-9 jam, sebagian besar metabolit terikat dengan protein dan didistribusi ke jaringan. Efek samping dari albendazole adalah nyeri epigastrium, diare dan muntah. Penggunaan jangka panjang menyebabkan rasa sakit gastrointestinal, sempoyongan, demam, alopecia, leukopenia dan trombositopenia (Syarif dan Elysabeth 2007 dalam Andrianty 2015).

Ivermectin bekerja dengan melumpuhkan dan membunuh parasit nematoda, araknida dan artropoda dengan efek yang unik pada sistem saraf parasit berupa hambatan neuro transmisi sehingga terjadi paralisa yang diikuti kematian. Ivermectin memiliki spektrum efikasi yang luas terhadap parasit internal dan eksternal dengan batas keamanan yang lebar, sehingga sangat ideal dipakai untuk kontrol parasit ternak. Injeksi Ivermectin sangat efektif terhadap segala stadium cacing pada ternak. Obat ini diindikasikan untuk pengobatan terhadap ektoparasit dan endoparasit seperti cacing pada saluran pencernaan, cacing paru-paru, cacing hidung, kutu, tungau, caplak pada sapi, kambing, domba dan babi. Obat ini diaplikasikan secara injeksi pada subkutan dengan dosis $2 \mathrm{mg} / \mathrm{kg}$ bobot badan (TMC 2019). 
Intermectin Super ${ }^{\circledR}$ mengandung 2 zat aktif yang bekerja sinergis, Ivermectin dan Clorsulon. Ivermectin termasuk golongan Avermectin, efektif membunuh ektoparasit dan cacing gelang saluran cerna, sementara Clorsulon termasuk golongan Benzenesulfonamide, untuk mengatasi infestasi cacing hati. Ivermectin dan Clorsulon efektif dalam melawan segala ektoparasit, endoparasit dan infestasi cacing hati pada sapi, kerbau, kambing dan domba. Obat ini diindikasikan untuk pengobatan terhadap ektoparasit dan endoparasit seperti cacing pada saluran pencernaan, cacing paru, cacing hidung, cacing mata, cacing hati, miasis (screw worm fly), oestrosis, kutu, tungau, caplak pada sapi, kerbau, kambing dan domba. Obat ini diaplikasikan secara injeksi pada subkutan dengan dosis $2 \mathrm{mg} / \mathrm{kg}$ bobot badan. Obat ini tidak boleh diberikan pada ternak bunting trimester pertama (TMC 2019).

Nitroksinil sangat efektif untuk pengobatan infestasi cacing hati atau distomatosis atau fascioliasis (cacing Fasciola hepatica dan Fasciola gigantica stadium larva dan dewasa). Nitroksinil juga aktif terhadap berbagai macam cacing pencernaan, Oestrus spp pada sapi, kerbau, kambing, domba dan anjing. Nitroksinil menghambat proses fosforilasi oksidatif pada mitokondria cacing yang menyebabkan kematian cacing tanpa efek samping dan sangat aman untuk hewan bunting. Obat ini diindikasikan untuk pencegahan dan pengobatan infestasi cacing hati (Fasciola hepatica dewasa dan larva umur lebih dari enam minggu, Fasciola gigantica) dan cacing pada saluran pencernaan (Haemonchus contortus, Haemonchus placei, Bunostomum phlebotomum, Oesophagostomum radiatum, Parafilaria spp dan Oestrus ovis). Obat ini diberikan secara injeksi pada subkutan dengan dosis $17 \mathrm{mg} / \mathrm{kg}$ bobot badan (TMC 2019). Infeksi kecacingan dapat dipengaruhi oleh beberapa faktor diantaranya kondisi lingkungan, pakan dan tata laksana pemeliharaan sapi perah (Paramitha et al. 2017). Sapi perah di KPGS Cikajang Garut dipelihara dalam kandang individual. Pemeliharan dalam kandang memungkinkan peternak lebih mudah untuk memastikan sapi dalam kondisi yang bersih, dapat mengontrol pemberian pakan dan jenis pakan yang diberikan. Menurut Nezar (2014), sapi yang dipelihara dengan cara diumbar akan lebih mudah mengalami gangguan akibat infeksi parasit daripada sapi yang dirawat dengan baik. Menurut Levine (1990) dalam Paramitha et al. (2017), manajemen pemeliharaan sapi yang 
buruk ditunjang dengan sanitasi dan kebersihan kandang yang kurang layak, kondisi lingkungan, iklim dan pakan yang terkontaminasi mempengaruhi terjadinya penyebaran penyakit, terutama infeksi kecacingan. Pakan yang diberikan pada sapi perah di KPGS Cikajang berupa hijauan maupun limbah pertanian dari sisa panen. Salah satu peternakan memberikan pakan berupa silase kepada sapi perah yang dipelihara. Hijauan telah dilayukan sebelum diberikan pada sapi perah di KPGS Cikajang Garut. Hal ini dapat mencegah terjadinya penyebaran cacing Fasciola gigantica (Info Medion 2013).

Faktor penting yang harus diperhatikan dalam pemeliharaan sapi adalah sanitasi kandang. Menurut BPTP Ungaran (2000) sanitasi kandang merupakan suatu kegiatan pencegahan yang meliputi kebersihan bangunan tempat tinggal ternak atau kandang dan lingkungannya dalam rangka untuk menjaga kesehatan ternak sekaligus pemiliknya. Kebersihan kandang merupakan hal yang penting dalam menjaga kondisi sanitasi kandang. Menurut Dairy NZ (2015) dalam menjamin kondisi kebersihan kandang maka diperlukan kebijakan dan prosedur untuk melakukan pembersihan kandang. Salah satu kebijakan atau prosedur pembersihan kandang pada peternak sapi perah yaitu melakukan pembersihan kotoran ternak secara rutin setiap harinya. Frekuensi dalam melakukan pembersihan kandang tergantung pada peternak masing-masing. Pada umumnya peternak yang tergabung di KPGS Cikajang melakukan sanitasi dua kali sehari yaitu saat akan dilakukan proses pemerahan sapi pada pagi dan sore hari.

\section{SIMPULAN}

Hasil pemeriksaan kecacingan secara kualitatif pada 82 sampel feses sapi perah di beberapa kelompok peternak KPGS Cikajang Garut menunjukkan hasil negatif. Hasil negatif disebabkan sapi perah tersebut telah diberi obat anti cacing secara rutin dan pemeliharaannya dilakukan secara baik. Obat anti cacing yang biasa diberikan pada sapi perah di KPGS Cikajang adalah Albenol-2500 ${ }^{\circledR} \quad$ (Albendazole 2500 mg) diberikan secara per oral yang dicampur pakan sapi, Intermectin ${ }^{\circledR}$ (Ivermectin 10 $\mathrm{mg}$ ), Intermectin Super ${ }^{\circledR}$ (Ivermectin 100 mg, Clorsulon $100 \mathrm{mg}$ ) dan Fluconix $-340^{\circledR}$ (Nitroksinil $340 \mathrm{mg}$ ) yang diaplikasikan secara subkutan.

\section{UCAPAN TERIMAKASIH}

Ucapan terimakasih penulis sampaikan kepada Kelompok Peternak Di KPGS Cikajang Garut. 


\section{DAFTAR PUSTAKA}

Agoes, R. 2009. Parasitologi Kedokteran: Ditinjau dari Organ Tubuh yang Diserang. Jakarta (ID): Penerbit Buku Kedokteran EGC.

Andrianty, V. 2015. Kejadian nematodiasis gastrointestinal pada pedet sapi bali di Kec. Marioriwawo, Kab. Soppeng. Makassar (ID): Universitas Hasanuddin.

Astiti, L.G.D. 2010. Petunjuk Praktis Manajemen Pencegahan dan Pengendalian Penyakit pada Ternak Sapi. Mataram (ID): Balai Pengkajian Teknologi Pertanian NTB.

[BPTP Ungaran] Balai Penelitian Tanaman Pangan Ungaran. 2000. Sanitasi Kandang Sapi Perah. Ungaran (Jawa Tengah) BPTP Ungaran.

[Dairy NZ] Dairy a New Zealand. 2015. Dairy Cow Housing - A Good Practice Guide for Dairy Housing in New Zealand. [pdf]. [Internet]. [diunduh 2019 April 21]. Tersedia pada: https://www.dairynz.co.nz/

Firdayana. 2016. Identifikasi telur cacing parasit pada feses sapi (Bos sp.) yang digembalakan di sekitar tempat pembuangan akhir sampah (TPAS) Tamangapa Makassar. [skripsi]. Makassar (ID): UIN Alauddin Makassar.

[Info Medion] Info Medion. 2013. Cacingan pada sapi jangan dianggap enteng. [Internet]. [diunduh 2019 April 21]. Tersedia pada:

https://info.medion.co.id/index.php/

artikel-hewan-besar/artikel-

pengobatan-vaksinasi/1047-

cacingan-pada-sapi-jangandianggap-enteng

Levine, G. 1994. Veterinary Parasitology. Ed ke 3. Illinois (US) : Cologe of Veterinary Medicine. University of Illinois.

Limpomo, A.B. 2014. Perbedaan metode flotasi menggunakan larutan $\mathrm{ZnSO}_{4}$ dengan metode KATO-KATZ untuk pemeriksaan kuantitatif tinja. [karya tulis ilmiah]. Semarang (ID): Universitas Dipenogoro.

Marhani, R.A.S. 2012. Studi diagnostik pemeriksaan feses menggunakan metode direct slide dengan metode konsentrasi dalam menegakkan diagnosis kecacingan. [skripsi]. Bandar Lampung (ID): Universitas Lampung.

Nezar, M.R. 2014. Jenis cacing pada feses sapi di TPA Jatibarang dan KTT Sidomulyo Desa Nongkosawit 
Semarang. [skripsi]. Semarang (ID):

Universitas Negeri Semarang.

Nono, P.L. 2017. Kecacingan pada mencit

(Mus musculus) di Unit Pengelolaan Hewan Laboratorium (UPHL) Fakultas Kedokteran Institut Pertanian Bogor. [skripsi]. Bogor (ID): Institut Pertanian Bogor.

Paramitha, R.P., Ernawati, R., Koesdarto, S. 2017. Prevalensi helminthiasis saluran pencernaan melalui pemeriksaan feses pada sapi di lokasi pembuangan akhir (LPA) Kecamatan Benowo Surabaya. Journal of Parasite Science. 1 (1): 24-27.

Prabowo, S.W. 2016. Infeksi cacing saluran pencernaan pada macan tutul sri lanka (Panthera pardus kotiya) di Taman Margasatwa Ragunan, Jakarta Selatan. [skripsi]. Bogor (ID): Institut Pertanian Bogor. Rahmadini, N.S. 2016. Uji diagnostik kecacingan antara pemeriksaan feses dan pemeriksaan kotoran kuku pada siswa SDN 1 Krawangsari Kecamatan Natar Lampung Selatan. [skripsi]. Bandar Lampung (ID): Universitas Lampung.

Regina, M.P., Halleyantoro. R., Bakri S. 2018. Jurnal Kedokteran Dipenogoro. 7 (2): 527-537.
Saefullah, A. 2012. Infestasi telur cacing parasitik pada tinja kerbau lumpur (Bubalus bubalis). [skripsi]. Bogor (ID): Institut Pertanian Bogor.

Siagian, T.B., Tiuria R. 2018. Worms Infestation on Stray Cats in Central Bogor. Hemera Zoa. 568-570.

Soulsby, E.J.L. 1982. Helminth, Arthropods and Protozoa of Domesticated Animal. 7th Ed. London (GB): The English Language Book Society and Bailliere Tindall.

Swierczynski, G. 2010. The search for parasites in fecal specimens. [Internet]. [diunduh 2019 April 24]. Tersedia pada: http://www.atlasprotozoa.com/index .php

Syarif, A. dan Elysabeth. 2007. Farmakologi dan Terapi (Ed. 5). SG. Gunawan, R. Setiabudy, Elysabeth, Eds. Jakarta (ID): Badan Penerbit FKUI.

Tantri, N., Setyawati, T.R, Khotimah, S. 2013. Prevalensi dan intensitas telur cacing parasit pada feses sapi (Bos sp.) rumah potong hewan (rph) Kota Pontianak Kalimantan Barat. Jurnal Protobiont. 2 (2): 102 - 106.

[TMC] Tekad Mandiri Citra. 2019. Albenol2500 bolus. [Internet]. [diunduh 2019 Maret 19]. Tersedia pada: 
http://www.temanc.com/produk/albe nol-2500-bolus

[TMC] Tekad Mandiri Citra. 2019. Intermectin. [Internet]. [diunduh 2019 Maret 19]. Tersedia pada: http://www.temanc.com/produk/inte rmectin

[TMC] Tekad Mandiri Citra. 2019. Intermectin super. [Internet]. [diunduh 2019 Maret 19]. Tersedia pada: http://www.temanc.com/produk/inte rmectin-super.

[TMC] Tekad Mandiri Citra. 2019. Fluconix-340. [Internet]. [diunduh 2019 Maret 19]. Tersedia pada: http://www.temanc.com/produk/fluc onix-340.

Zalizar, L. 2017. Helminthiasis saluran cerna pada sapi perah. Jurnal IImuIImu Peternakan. 27 (2): 116-12. 